\title{
THE LIFE SALVOR PROBLEM IN ADMIRALTY
}

\section{LAWMENGE JARETTं}

IT is a confounding fact that American admiralty law grants greater material reward for saving cattle in danger at sea than people in similar jeopardy. In The Dalzellea, for example, a tugboat was awarded $\$ 6,000$ for salvage services to a cattle float having a net salved value of over $\$ 86,000 .^{1}$ Well over three-quarters of the salved value, however, was contributed by the worth of some 3500 animals. If the salvor had saved men, women and children instead of animals, his reward would have been based on the value of the damaged float alone. And if this float had sunk, he would have been turned away by our courts without a penny, despite a successful rescue of passengers and crew, since a life salvage award, if granted, is dependent upon property being saved. ${ }^{2}$

The life salvor is a problem of law and morality.3 The general maritime law, like the common law, "does not compel active benevolence between man and man," and "it is left to one's conscience whether he shall be the Good Samaritan or not." Although the most elementary instincts of humanity seemingly impose a duty to assist those in distress on the watery highways of the world, it was not until 1910 that the great maritime nations of the world agreed to put legal compulsion behind this obvious moral obligation." In that year the International Salvage Convention proposed the imposition of a duty upon each ship master, "so far as he can do so without serious danger to his vessel, her crew and passengers, to render assistance to everybody, even though an enemy, found at sea in danger of being lost." 3 Fulfilling its responsibility as a Convention signatory, the United States enacted this proposal

iMember, New York Bar. Associate Professor of Law, United States Merchant Miarine Academy.

1. 12 F. Supp. 179 (S.D.N.Y. 1935).

2. See 1 Norris, The Law of Seajuen $\$ \$ 212,237$ (1951).

3. Life salvage may be defined as a reward given by law, from reasons of public policy, humanity and commerce, for saving human life in danger at sea. Sce Dunlop, Life Salvage, 15 Scot. L. REv. 44 (1S99).

4. Ames, Law and Morals, $22 \mathrm{Hanv}$. L. REv. 97, 112 (1908). The failure of admiralty to develop an equitable award rule for the life salvor becomes less shocking if one surveys judicial and jurisprudential discussion devoted, with unsatisfactory and conflicting results, to the problem of reconciling moral considerations and legal obligations. See Crrsozo, The Paradoxes of Legal Sctences 25 (1928); Robinson, Hanoroos of Adxulultz Law 722 n.44 (1939); Allen, Lcgal Duties, 40 YaLe L.J. 331 (1931).

5. See Standard, International Conzintions and the Rights of Scanom, Passingers and Shippers, 5 LAw. Guind Rev. 368 (1945).

6. Int'l Salvage Convention Art 11 (1910). The Convention also provides that "the owner of the vessel incurs no liability by reason of contravention of" Article 11, ibid.; and that "The High Contracting Parties whose legislation does not forbid infringe- 
into the Salvage Act of 1912, providing for the fining and imprisonment of violators. ${ }^{7}$ But while a master is threatened with a criminal penalty for failing to save the lives of others, performance of this duty does not bring him material reward. Moreover, there is no provision for repayment of any loss the master, shipowner, or crew may suffer in saving lives. ${ }^{8}$ That maritime law should reward the property salvor, but not the life salvor, is a paraldox that requires an examination of the fundamental elements of the salvage concept in general, and the life salvage concept in particular.

An analysis of the innumerable salvage definitions reveals that at least three basic elements must be present to support the validity of a salvage claim. First, there must be a service to maritime property ${ }^{\circ}$ which is in real or impending danger. ${ }^{10}$ Secondly, the service must be voluntary in nature. ${ }^{11}$ Thirdly, there must be at least partial success in saving property, or a proximate contribution to the ultimate success. ${ }^{12}$ Behind the concept of

ments" of Article 11 "bind themselves to take or to propose to their respective legislatures the measures necessary for the prevention of such infringements." Id., Art, 12. For a full text of the treaty, see 6 Benedict, AdMiralty 200 (6th ed., Knauth, 1941).

7. Section 2 of that Act states: "That the master or person in charge of a vessel shall, so far as he can do so without serious danger to his own vessel, crew, or passengers, render assistance to every person who is found at seas in danger of being lost; and if he fails to do so, he shall, upon conviction, be liable to a penalty of not excecding $\$ 1,000$ or imprisonment for a term not exceeding two years or both." 37 STAт. 242 (1912), 46 U.S.C. $\$ 728$ (1946). See Warshaver v. Lloyd Sabado S.A., 71 F.2d 146 (2d Cir.), cert. denied, 293 U.S. 610 (1934) (shipowner not liable for master's failure to render assistance). See Robinson, op. cit. supra note 4, at 723.

8. In this regard, see Article III of The Aviation Salvage at Sea Convention of 1938 which contains provisions relative to giving "a right to an indemnity in respect of expenses justified by the circumstances and of losses suffered in the course of the operations." For complete text of this convention, see 6 BENEDICT, op. cil. supra note 6, at 203 . See Knauth, The Aviation Salvage at Sea Convention of 1938, 10 AIR L. REv. 146 (1939).

9. See, e.g., Cope v. Vallette Dry Dock Co., 119 U.S. 625, 629 (1887) (fixed drydock not subject to salvage) ; but cf. Steamship Jefferson, 215 U.S. 130 (1909) (vesscl catching fire while under repair in dry dock held subject to a salvage award).

10. The Urko Mendi, 216 Fed. 427 (E.D. Pa. 1914); Boardman v. The Bethel, 3 Fed. Cas. 778, No. 1,585 (S.D.N.Y. 1849); The Phantom, 1 L.R. Adm. \& Eccl. 58 (1866); The Charlotte, 3 W. Rob. 68, 166 Eng. Rep. 888 (1848).

The fact that the peril is slight will not deprive the operation of its nature as a salvage service, but will, of course, influence the amount awarded. Clayoquot Sound Canning Co. Ltd. v. S.S. Princess Adelaide, 48 D.L.R. 478 (Ex. 1919); The Andrew Kelly v. The Commodore, 48 D.L.R. 213 (Ex. 1919).

For analysis of elements to be considered in fixing the amount of a salvage award, see The Toledo, 136 Fed. 959 (S.D.N.Y. 1905); The Lyman M. Law, 122 Fed. 816 (D. Me. 1903). See also Kennedy, The Law of Civil Salvage 151 (3d ed. 1936).

11. "The whole theory of salvage is predicated upon the proposition that . . . therc is no legal duty to aid a thing or person who is in distress." Roninson, op. cit. supra note 4, at 722. See The Hope, 10 Pet. 108 (U.S. 1836). See also KENNEDY, op. cit. supra note 10 , at 2 .

12. The Annie Lord, 251 Fed. 157 (D. Mass. 1917); The Strathnevis, 76 Fed. 855 (D. Wash. 1896). Also see, The Blackwall, 10 Wall. 1, 12 (U.S. 1870). 
salvage are basic elements of public policy that recognize both the humanitarian need of aiding ships in distress, and the commercial importance of maritime trade..$^{13}$

The antiquity of salvage is the antiquity of maritime trade itself. ${ }^{14}$ Since the seas were the primary highways of commerce when maritime customs were developing, merchants and traders influenced the evolution of maritime law. ${ }^{15}$ The earliest maritime codes speak of salvage awards as proportions of property saved, and give no consideration to any award for saving lives. ${ }^{10}$ The law of salvage was intended to motivate the saving of property for the benefit of owner and salvor alike, and experience quiclily proved a material reward to be the most efficacious method of achieving that end. Consequently, the salvor has a lien of highest priority upon the property saved, whether ship or cargo. ${ }^{17}$ This lien accrues immediately upon the performance of the service, and gives the salvor a right to proceed in roin against the property itself. $^{18}$ If necessary, the property may be sold, and the salvor may have his claim satisfied from the proceeds of the sale. ${ }^{10}$

This in rem association of the salvor's reward with the property saved undermines the legal status of the life salvor. The mere mentioning of a salvage award as a right in rein is sufficient to spell out the fundamental incompatibility involved in seeking to develop the life salvage concept..9 England's Admiralty Court denied life salvage where no property had been saved, because free bodies could not be valued."1 However, if life and property were

13. In The Star, 53 F.2d $\$ 90$ (W.D. Wash. 1931), an alleged custom among fishermen to render reciprocal aid as a substitute for salvage was held contrary to public policy since the court could not say that the incentive furnished by such custom was as strong as the incentive furnished by the right to demand a salvage award in admiralty. Contra: The Freeya v. The R.S., 59 D.L.R. 330 (Ex. 1921) ; 35 HAsv. L. REr. 615 (1922).

In The Blaireau, 2 Cranch 240, 266 (U.S. 1804), the Court said: "The allowance of a very ample compensation for [salvage] services ... is intended as an inducement to render them, which it is for the public interests, and for the general interests of humanity, to hold forth to those who navigate the ocean."

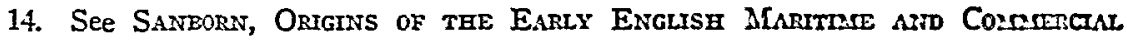
LAw 26 (1930).

15. "[MI]aritime law ... did not arise from the learning or speculations of theorists." Putnam, The Remedy for Death at Sca, 22 CAse \& Coxonornt 125 (1915).

16. See, e.g., Ashburner, The Rhodnan Sea-Law, cclmaviii-ccieiii (1909).

17. The salvage lien may command precedence even over prior earned seamen's wages. The Conveyor, 147 Fed. $5 \& 6$ (D. Ind. 1906); The Nettie Woodward, 50 Fed. 224 (E.D. Mich. 1892).

18. Canfield, Salvage, 22 Case \& Comanent 118 (1915). See, The Charlotte Wylie, 2 W. Rob. 495, 166 Eng. Rep. S42 (1S46).

19. Carver, Carriage of Goods by Sea 485 (Sth ed, Henderson, 1938).

20. The lack of life salvage awards may be due to the fact that "the salvor could hardly be allowed to detain the body of the person whom he saved ... until the salvage was paid for his release." Knauth, Ariation and Salazge: The Application of Salvage Principles to Aircraft, 36 CoL. L. Rev. 224, 223 (1936).

21. SANBorN, op. cit. supra note 14, at 15. For the origin of this rationale in Roman law, see $i d$. at 39. Also see The Zephyrus, 1 W. Rob. 329, 331 (1842) (jurisdiction of 
saved simultaneously, the Court tended to give larger awards than if property alone were saved. ${ }^{22}$

Improving upon the general maritime law, the present law of life salvage in Great Britain gives considerable recognition to the claims of life salvors. A series of statutory enactments, ${ }^{23}$ culminating in the Merchant Shipping Act of $1894,{ }^{24}$ has removed the barriers of general maritime law. The salvor of life from a British vessel anywhere, or from a foreign vessel when the act occurs wholly or in part in British waters, has an independent right to claim a life salvage award. ${ }^{25}$ The award is based on the cost of the "actual expenses incurred" in the life salvor's rescue operations plus "reasonable" compensa-

salvage court is founded solely upon a proceeding against property and not against the person).

22. Mactachlan, Merchant Shipping 713 (5th ed., de Hart \& Bucknill, 1911.).

23. The earliest statute to direct payment of a "reasonable reward" to properly salvors was enacted in 1713. 13 Anne c. 21. Not until 1821, however, was the admiralty court given power to award salvage for life saving apart from property saving. 1821, 1 \& 2 Geo. IV, c. $46, \S 8$. See KENNEDY, op. cit. supra note 10, at 56. Compare The Queen Mab, 3 Hagg. 242 (1835) (although no property was saved, an award was granted for assistance in saving the lives of the crew), with The Zephyrus, 1 W. Rob. 329 (1842) (unless property was salved, no award for life salving was possible).

Following The Zephyrus, a new statute provided that "every person . . . who shall act ... in the saving ... of the life of any person on board ... shall ... be paid a reasonable reward $\ldots$ by way of salvage for such service...." $1846,9 \& 10$ Vict., c. $99, \S 19$, The Silver Bullion, 2 Spinks, E. \& A. 70 (1854) (returning to The Quecn Mab rule).

The 1846 Act was repealed since it failed to indicate either by whom or how payment was to be made. Merchant Shipping Repeal Act, 1854, 17 \& 18 Vict., c. 120, \$5. A new statute clearly set forth the life salvage liability, indicated by whom it should be borne, and gave a life salvage claim the highest priority. Merchant Shipping Act, 1854, 17 \& 18 Vict., c. 104, $\S 458,459$, The Coromandel, Swab. 205 (1857). A special fund was set up to meet a life salvor's claim if property salved proved inadequate. See, e.g., The Cargo ex Schiller, 2 P.D. 145, 158 (1877).

Even under the 1854 statute, however, it was still necessary for some property to be saved, either by the life salvor or another salvor, for the life salvor to recover anything. The Renpor; 8 P.D. 115 (1883). See also, The Mariposa, (1896) p. 273; Marsden, Law of Col.lisions at SEa 130 (9th ed., Gibb, 1934); Dunlop, supra note 3, at 46. But the 1854 statute was operative only for salvage rendered within three miles off the shore of the United Kingdom. The Leda, Swab. 40 (1856). Because of this obvious defect, the legislature responded with the Admiralty Court Jurisdiction Act, 1861, 24 Vict., c. 10, §9, The Pacific, (1898) p. 170; The Cairo, 2 Asp. 257 (1874) (applicable to British ships wherever they might be and to foreign ships in British waters); and the Merchant Shipping Act Amendment Act, 1862, 25 \& 26 Vict., c. 63, §59 (extending the principle of life salvage to foreign ships outside British waters if the foreign power was amenable to British courts awarding salvage). But $\S 59$ of the second act has been applied only to Prussia. See Order in Council, April 7, 1864, saved by Merchant Shipping Act, 1894, $57 \& 58$ Vict., c. $60, \S 745$.

24. $57 \& 58$ Vict., c. 60.

25. " $\$ 544$ (1) Where services are rendered wholly or in part within British waters in saving life from any British or foreign vessel, or elsewhere in saving life from any British vessel, there shall be payable to the salvor by the owner of the vessel, cargo, or 
tion. ${ }^{26}$ If vessel or other property is saved or later recovered by anyone, these properties are subject to the life salvor's claim in proportion to their value. ${ }^{27}$ Moreover, as against the owner of the surviving vessel, the life salvor's award takes priority over all other claims for salvage; $;^{\text {ss }}$ as against owners of all other surviving property, the award has at least equal standing with other salvage claims. ${ }^{20}$ The liability of owners of surviving property to pay life salvage does not exceed the value of such property; however, there is a qualified right to proceed in personam to the limit of the value of defendant's interest in such property. ${ }^{30}$ Where vessel and all other property are lost, or where their surviving value is too small to satisfy the award to the life salvor, the Board of Trade may pay the claim, in whole or part, out of money provided by Parliament in a Mercantile Marine Fund. ${ }^{31}$

\section{The Life Salvor in Aarerican Adamiralty Courts}

Life salvage awards were made in a paradoxical fashion in colonial America. Since slaves were regarded as property, their salvors were granted awards, 32

apparel saved, a reasonable amount of salvage, to be determined in case of dispute in manner hereinafter mentioned.

"(2) Salvage in respect of the preservation of life when payable by the owners of the vessel shall be payable in priority to all other claims for salvage.

“(3) Where the vessel, cargo and apparel are destroyed, or the value thereof is insufficient, after payment of the actual expenses incurred, to pay the amount of salvage payable in respect of the preservation of life, the Board of Trade may, in their discretion, award to the salvor, out of the Mercantile Marine Fund, such sum as they thinls fit in whole or part satisfaction of any amount of salvage left unpaid.

"\$545. When it is made to appear to Her Majesty that the government of any foreign country is willing that salvage should be awarded by British Courts for services rendered in saving life from ships belonging to that country, when the ship is beyond the limits of British jurisdiction, Her Majesty may, by order in Council, direct that the provisions of the part of this Act with reference to salvage of life shall, subject to any conditions and qualifications contained in the order, apply, and those provisions shall ascordingly apply to those services as if they were rendered in saving life from ships within British jurisdiction." The Merchant Shipping Act of 1894, 57 \& 58 Vict, c. 60, \$\$ 544, 545.

These sections essentially re-enact the corresponding sections of the MFerchant Shipping Act, 1854, and its extensions by the Admiralty Jurisdiction Act, 1861, $\$ 9$; and the Merchant Shipping Act Amendment Act, 1862, \$59. See note 23 supra.

26. See note 25 supra.

27. The Longford, 6 P.D. 60 (1880). Also see, Lowndes \& Rurolpu, Lay of General Averages 152 (7th ed. 1948).

28. See $\$ 544(2)$, supra note 25.

29. The Cargo ex Sarpedon, 3 P.D. 28 (1877); The Cargo ex Schiller, 2 P.D. 145 (1877).

30. See, e.g., The Cargo ex Port Victor (1901) P. 243; Dunean v. Dundee Shipping Co., 15 Scot. L.R 429 (1878) ; The Cargo ex Schiller, 2 P.D. 145, 147 (1877). Also see KENAEDY, op. cit. supra note 10, at 13 et scq. The in personans remedy is resorted to infrequently. See, e.g., Five Steel Barges, 15 P.D. 142 (1890); The Rapid, 3 Hag. Adm. 419 (1838); The Hope, 3 C. Rob. 215 (1801).

31. See $\$ 544(3)$, stipra note 25.

32. Flinn v. The Leander, 9 Fed. Cas. 275 , No. 4,870 (D.S.C. 1S08); Jerby v. One Hundred and Ninety-four Slaves, 13 Fed. Cas. 550, No. 7,2SS (D.S.C. 1806); Bass v. 
apparently without courts' perceiving that they were thus indirectly encouraging the saving of slaves in preference to freemen. While this policy might have found favor in the eyes of the early abolitionists, it could hardly have been the intention of the jurist or the slave owner (sometimes the same person). Yet, trapped by mores and law that made men chattels, the courts were compelled to make remuneration to those who saved slaves, since slaves had a market value while freemen did not. ${ }^{33}$ The life salvage problem thus appeared indirectly in early America as a problem of "property" salvage.

But the life salvage doctrine in America inexplicably failed to duplicate the English development. Although our courts cast envious glances across the Atlantic toward the English recognition of the life salvor, ${ }^{34}$ they felt compelled to adhere, in the absence of legislation, to the established general maritime rule that the saving of life alone could not be rewarded..$^{35}$ Of course, when a life salvor saved property too, the courts could be more generous..$^{30}$ But even here, the judiciary realized that remedial legislation was both necessary and desirable; they were reluctant to take more of $A^{\prime}$ 's property to reward $B$ for having saved $C .{ }^{37}$ Failure to provide the required legislation must be placed at Congress' doorstep.

\section{The Present Life Salvage Statute:}

Concomitant with United States ratification of the International Salvage Convention, ${ }^{38}$ Congress enacted the present law on life salvage. Under the Salviage Act of 1912:

"Salvors of human life who have taken part in the services rendered on the occasion of the accident, giving rise to salvage

Five Negroes, 2 Fed. Cas. 1006, No. 1,093 (D.S.C. 1803) ; see also, Recorns of THE VICEAdmiralty Court of Rhode Island, 1716-1752 p. 226 (Towle ed. 1936) ; Reports of Cases in the Vice-Admiralty of the Province of New York and in tae Court of Admiralty of the State of New York, 1715-1788 p. 73 (Hough ed. 1925); Marvin, A Treatise on the Law of Wreck and Salvage 240 (1858).

33. See The Mulhouse, 17 Fed. Cas. 962, 967, No. 9,910 (D.Fla. 1859).

34. See The Plymouth Rock, 9 Fed. 413, 418 (S.D.N.Y. 1881) ; Lamar v. Penclope, 14 Fed. Cas. 977, No. 8,007 (E.C. S.C. 1858).

35. See cases cited note 34 supro. It is perhaps significant that an early Amcrican treatise on maritime law, although discussing the seaman's right to salvage, is silent on the question of life salvage or the right thereto. See CuRTIS, A TREATISE ON THE RIGHTS and Duties of Merchant Seamen (1841).

36. The saving of life "forms an essential ingredient where the question of compensation is under consideration." The Edith L. Allen, 139 Fed. 888, 893 (S.D.N.Y. 1905). Also see The Kaiser Wilhelm der Grosse, 106 Fed. 963 (S.D.N.Y. 1901); The Emblem, 8 Fed. Cas. 611, No. 4,434 (D.Me. 1840).

However, despite such statements a recent comprehensive study of salvage awards apparently concludes that the difference in the assessment where property alone, and where both property and lives are salved, is of "a comparatively minor nature." See Sutton, The Assessing of Salvage Awards 576, 577 (1949).

37. Ibid.

38. See 6 BENEDICT, op. cit. supra note 6. 
or assistance, are entitled to a fair share of the remuneration awarded to the salvors of the vessel, her cargo, and accessories."39

Thus worded, this statute "merely perpetuates the previous rule that property must be saved if the salvors of life are to get anything, and that the salvors get their reward out of the property saved." 40 Moreover, even if property is saved, the life salvage must take place "on the occasion of" such saving. Judicial interpretation of the statute did not enhance the status of the life salvor.

The In re St. Joseph-Chicago S.S. Co. ${ }^{11}$ decision limited the right of a life salvor to receive a life salvage award. When an excursion vessel, the Eastland, sank at its dock in the Chicago River on July 24, 1915, more than 800 persons were killed. The loss of life would have been even greater were it not for the "magnificent and heroic efforts of the life salvors" who bent every effort to save as many of the passengers and crew as possible.92 Since the Eastland's owner was legally obligated to raise and remove her quickly, a "no cure, no pay" salvage contract was concluded with the Great Lakes Towing Company on July 27, and the vessel was raised by August 16.23 As the life salvors had contributed nothing to the saving of property, it was conceded that apart from statute they had no claim. The court was faced with deciding whether the life salvors were entitled, under the statute, to a share of the contract remuneration made to the towing company.

The court denied the life salvors' claims on several grounds. First, the life salvors had not filed their claims within the period set by the statute.4s Secondly, the court construed the statute as not granting an award to a life salvor if the life salvage or the property salvaged did not occur "during the period of peril." 45 Since the services of the Towing company occurred a considerable time after the pericd of peril, the life salvors could not come under the statute. ${ }^{46}$ Moreover, since the life salvors could not have saved

39. 37 STAT. 242 (1912); 46 U.S.C. $\$ 729$ (1946). The purpose of this statute was to harmonize United States' law with the provisions of the "salvage treaty adopted at the Third International Conference on Maritime Law held at Brussels in 1910." The Impoco, 287 Fed. 400, 403 (S.D.N.Y. 1922).

40. Rominson, op. cit. sutpra note 4, at 718 .

41. 262 Fed. 535 (N.D. Ill. 1919).

42. Id. at 536 .

43. Id. at 537.

44. Id. at 541-5.

45. Id. at 541. See note 53 infra.

46. "The services rendered in the saving of lives were to be considered when remuneration for salvage was awarded, so that they might particjpate in and be given a part of any sum paid for saving the vessel or other property. In such a case, the life salvor, by virtue of his service rendercd at the time that the property was saicd, beeame a cosalvor, with a right to recover compensation for a service, when under the general maritime law, he would get nothing.... It was not intended that, as between difierent sets of salvors, the life salvor was to participate in awards which might be made for services 
the Eastland, they were not life salvors which the statute was intended to reward, namely, those who might otherwise be tempted to devote their efforts to save the vessel, leaving the people to perish. ${ }^{47}$ The court found compensation for these salvors on a spiritual level: "What they did was inspired by the spirit which since Christendom has been the foundation of the great brotherhood of mankind. . . . Their reward they have; it can never be taken from them, and it is measured by a standard greater than money."48

One must perforce sympathize with any jurist who finds the law in such a state that he must resort to sermonizing in order to rationalize his decision. Not tempted by evil, the life salvors could not, under the statute, be rewarded for doing good. Moreover, had the life salvors here felt that "virtue is its own reward," they would not have taken affirmative action to obtain a more material manifestation of virtue. Rewards "greater than money" are not within the province of admiralty courts to dispense.

The scope of the statute was further restricted in The Admiral Evans.40 Libellant brought an in rem action against a salved vessel to recover for services renclered and damages suffered by his vessels which had participated in the removal of passengers, baggage and mail. The court denied an award on the ground that since libellant did not participate in salvaging the vessel, no claim could be asserted against it either for rescuing passengers or for salvaging cargo.50 The court interpreted the statute as placing "human life and property on a par to excite interest of salvors to save life, as well as ship and cargo, but [that] to warrant award for saving life a salvage claim must exist against the ship or cargo." ${ }^{11}$ Since the life salvage claim in this action was asserted against the vessel, and since this claim, like that for salvaging cargo, failed because libellant did not participate in salvaging the vessel, the statute was worthless to the life salvor. ${ }^{52}$

The Adniral Evans reveals the practical inadequacy of our present legislation. According to the court, congressional intent was to place "life and property on a par." But life can not be placed on a par with property if the life salvage award depends upon some property being saved. Any would-be life salvor motivated primarily by hope of gain would initially save property, or assist in the saving of property, to assure the existence of an adequate salvage fund. Having thus assured himself of a source for a salvage award, he might then turn to saving life in order to enhance his share of the award. Only by making the life salvage award independent of the necessity for any

rendered months, and even years, after the life-saving service had been performed." Id. at 540-1 (emphasis added).

47. Id. at 539,540 .

48. Id. at 540 .

49. 286 Fed. 442 (W.D. Wash. 1923).

50. Id. at 443 .

51. Ibid.

52. Benedict suggests that The Admiral Evans raises the possibility of a remedy in personam existing in life salvage cases, but finds no authority for such position. Sce 1 BENEDICT, op. cit. supra note 6 , at 338 n.23. 
property salvage can the saving of life be made the monetary equal of the saving of property. ${ }^{53}$

\section{New legislation:}

An independent status for the life salvor in America requires new legislation. This legislation might parallel British statutes on the subject, but it should, where feasible, go beyond British law in order to enact comprehensive inducements which would encourage life salvage endearors. Fortunately, such endeavors are today required with growing infrequency, but when they are required, the stakes are as great as they ever were. Remedial legislation should remove effectively any temptation to save property rather than life, and should recognize that a life salvor may be in greater peril saving lives than saving property. ${ }^{54}$ This means that the life salvage award must be completely adequate, reasonably certain, and independent of the contingency of property survival. And, where the life salvor contributes in any way to property salvage, his property salvage rights should not be affected by his life salvage claim. Moreover, the statute should provide for reimbursement of the life salvor for any expenses or losses incurred in the course of operations directed primarily toward saving persons. .5

Since the life salvor should be rewarded even if no property survives, the statute must provide a new source for his remuneration. The persons saved are a possible source of payment, for they are the direct recipients of the life salvor's efforts. While Article 9 of the Salvage Convention specified that "no remuneration is due from the persons whose lives are saved," it then added, "nothing in this Article shall affect the provisions of the national laws on this subject." Although the present life salvage statute is silent in this regard, ${ }^{57}$ Article 9 apparently acknowledges the possibility of future national legislation holding the rescued financially liable. One commentator has strongly urged that the persons saved be personally liable, arguing that ascertaining the proper award would be no more difficult than estimating damages in a wrongful death action, and that this award should not be paid by a shipowner "who, in many cases, is in no way benefited" by the life salvage. ${ }^{.5}$

53. In The Shreveport, 42 F.2d 524 (E.D. S.C. 1930), the court awarded the Aldece $\$ 5,000$ as life salvage for having taken off the crew of the burning Shreveport. The Shreveport was salvaged later the same day by the Mfariners Harbor after the Aldeco3 had left the scene. The court held that the statute should be "liberally construed with the humane object in view" and found that the life salvage services were rendered "on the occasion of the accident giving rise to salvage." But of. The Doctor George J. Moser, 55 F.2d 904 (2d Cir. 1932); Barge 592-Delroy, 193S Am. MIar. Cas. 57 (E.D. Pa. 1937).

54. RoBInson, op. cit. supra note 4, at 717. For the consideration to be given to the element of danger to the lives of the salvors in fixing the amount of a salvage award, see The Toledo, 136 Fed. 959 (S.D.N.Y. 1905).

55. See note $\&$ supra.

56. Int'l Salvage Convention Art. 9 (1910).

57. The otherwise comprehensive life salvage provisions of the Aviation Salvage at Sea Convention of 1938, see note 8 suspra, are equally silent in this respect.

58. Cunningham, Life Saliage, 17 Green Bag 708, 709 (1905). 
This solution is beguiling in its simplicity, and must be rejected.50 If the person saved is financially unable to pay a reward, the life salvor is left empty-handed after performing a service in the public interest. Moreover, in assessing damages in wrongful death actions the heirs' loss is in issue, and this is far different from a humiliating evaluation of living persons in monetary terms. And finally, it is doubtful that a shipowner is "in no way benefited" by life salvage. Both ship and cargo owners are potential benefactors of prompt life salvage. ${ }^{60}$ The removal of passengers conceivably may permit more expeditious and effective rendering of property salvage services. And while any effort to increase the attractiveness of services to life rather than to property contains a latent financial disadvantage for property owners and their underwriters, an enlightened "just regard" for the general interest of maritime commerce cannot permit indifference to any plan to further the safety of passengers and crew. ${ }^{61}$

If the reward is not to be paid by the persons saved, the maritime property owners must bear the expense of life salvage remuneration. The salvage relationship between the United States Coast Guard and these property owners offers a feasible method of distributing this burden. ${ }^{62}$ Since the extensive salvage services of the Coast Guard do not bring any award to the Government, it is not surprising that, whenever expedient, "shipmasters in trouble try to wait for the Coast Guard's free aid."63 Furthermore, when a Const Guard vessel and a private salvor both participate in a salvage operation, the share of the award which would normally go to the Coast Guard vessel remains with the owner of the property saved, constituting in effect a gift of the government. ${ }^{64}$ Since the American public contributes to the saving of his

59. See 19 HARv. L. REv. 310 (1906) (review of Cunningham, note 58 supra).

60. "If any definite value had to be put on the saving of life, a possible standard would be that of the shipowner's liability for the loss of life. With the crew, this would ordinarily be that of the Workmen's Compensation Acts, with passengers ordinarily no liability at all. Given, however, some prior actionable fault on the shipowner's part, the basis of which would be different as between passengers and crew, the liability in both cases would be that for common law damages." See Surron, op. cit. supra note 36, at 45.

61. "The ground ... for charging the ship with the payment of salvage of life is not the actual benefit received by the shipowner in the particular case. The sume reasoning applies to cargo. . . . But the direct benefit is not the sole principle upon which salvage reward is required to be paid. . . . Salvage is governed by a due regard to benefits received, combined with a just regard for the general interests of ships and marine commerce." The Fusilier, 1 Br. \& L. 341,347 (1865).

62. The Coast Guard is authorized to cruise upon the coast in the season of scvere weather and "afford such aid to distressed navigators as their circumstances may require." 5 STAт. 208 (1837), 14 U.S.C. $\$ 53$ (1946). The Coast Guard's "cutters cruise in quiet seasons as well as stormy and the extension of its. free services in the morc crowded waters throughout the year has tended to discredit the professional and amateur salvor in the public eye; the professional salvor seems to survive only for the heavier jobs which the Coast Guard does not undertake." Knatuth, stipra note 20, at 244.

63. Id. at 245 .

64. See, e.g., United States v. Central Wharf Towboat Co., 3 F.2d 250, 251 (1st Cir. 1924); The Kanawa, 254 Fed. 762, 764 (2d Cir. 1918); The Borgfred, 1936 Am. Mar. Cas. 804,810 (D.C. Virg. Is.). 
property, the owner can hardly be heard to complain should he be required to pay a relatively small sum into a fund established to give greater security to the members of that public when they travel by sea.

The presently gratuitous services rendered by the Coast Guard should be the source of income for a United States Life Salvage Fund. When the Coast Guard renders successful salvage services to maritime property under circumstances which would justify a salvage award had the services been rendered by a private party, the owner of such salved property should pay one percent of its reasonable value into a United States Life Salvage Fund. Since private salvage awards, at the extreme low range of the scale, generally run from two to five percent, ${ }^{6 J}$ the one percent required would still leave the property owner in an advantageous position when the Coast Guard rather than a private salvor aids his vessel.

The power of the United States Government to demand remuneration for salvage services rendered by its vessels is not to be denied. ${ }^{63}$ The payment into the Fund, however, would not be a change in the traditional policy of the Government not to demand salvage payment for services rendered by Coast Guard vessels and their personnel. It would not be a salvage award in any accurate sense, because the element of voluntariness is lacking in the case of the Coast Guard, ${ }^{67}$ and because the amount of the payment would not be subject to such variable elements as the efforts, peril and skill of the salvor, and the value of the salvor's equipment. ${ }^{6 s}$ The payment would be closer to a fee paid into a special fund for a special maritime purpose, and might be viewed as a measure of repayment by the American shipowner to the American taxpayer for the monetary benefits conferred in the form of governmental subsidies and other assistance.

\section{CONCLUSION}

The injustice inherent in the present American law of life salvage is manifest; remedial legislation is necessary. It is submitted that the following

65. See Knauth, supra note 8 , at 226; tables set forth in Surror, op. cil. supra note 36 , at 74 et seq.

66. "The Secretary of the Navy is authorized to cause vessels under his control adapted to the purpose to afford salvage service to public or private vessels in distress; Provided, That when such salvage service is rendered by a vessel specially equipped for the purpose or by a tug, the Secretary of the Navy may determine and collect reasonable compensation therefor." 40 STAT. 705 (1918), 34 U.S.C. $\$ 472$ (1946).

In The Omaha, 71 F. Supp. 314 (D.P.R. 1947), aff'd sub snom Hamburg-American Line v. United States, 168 F.2d 47 (1st Cir. 1948), members of a U.S. Naval vessel's crew boarded a German merchant vessel, whose crew had scuttled and abandoned her, and were awarded salvage in actions $i$ rem filed in their behalf by the United States. See The Impoco, 287 Fed. 400 (S.D.N.Y. 1922).

67. See note 11 supra and accompanying text.

68. For the variable elements to be involed in awarding a traditional salvage claim, see The Toledo, 136 Fed. 959 (S.D.N.Y. 1905); The Lyman M1. Law, 122 Fed. 816 (D. Me. 1903) ; KENNEDY, op. cit. suppra note 10, at 151. 
statute embodies the essentials required to remedy the anomalies of the present law:

\section{Section I. Life Salvor Remuneration: Award and Reimbursemcnt}

(a) Salvors of human life from any vessel whose services are rendered wholly or in part within the navigable waters of the United States, its territories or possessions, or from a vessel of United States registry anywhere on the high seas, shall be entitled to a reasonable award as life salvage remuneration regardless of whether the vessel, cargo or any other property shall survive the distaster giving rise to such life salvage services, and without consideration of any requirement that such salvors of human life render salvage services of any kind to the vessel, cargo, or any other property which may survive the said disaster.

(b) Any person shall also be entitled to reimbursement for any expenses or losses which are directly attributable to life salvage endeavors, whether successful or not. ${ }^{60}$

\section{Section II. Procedure}

(a) The Secretary of Commerce is authorized and directed to establish a United States Life Salvage Administration Board to consist of three members, one representative each from the Coast Guard, the Maritime Administration, and the federal judiciary. This Board shall be empowered, under such rules and regulations as it may prescribe, to ascertain a reasonable award and reimbursement on any occasion where no vessel, cargo or other property survives the disaster giving rise to the life salvage claim, or where the vessel, cargo, or other property so surviving shall be of insufficient value for life salvage remuneration.

(b) When vessel, cargo and other property fail to survive the distaster, or when the value of surviving vessel, cargo or other property is insufficient for award and reimbursement, a life salvor may file a claim for remuneration with the Board. Any remuneration so received shall be deemed in lieu of any right to claim award or reimbursement from any other source. ${ }^{70}$

\section{Section III. Ascertaining Award and Reimbursement}

(a) In determining the amount of life salvage award, the Board shall consider the following factors:

69. This section would not apply to life salvage rendered to foreign vessels ottside American territorial waters, unless some agreement for reciprocity existed, as provided for in British law. See note 23 supra.

70. This section enables a life salvor, where no property survives the disaster, to seek a life salvage award by direct administrative procedure. It is contemplated that if any property survives, the life salvor will exercise his right to intervene in the property salvage proceedings for his reward. If, however, a life salvor is denied an award in these proceedings because of insufficiency of surviving property, he may then apply to the Board for an adequate award. Similarly, the life salvor may in the first instance seek award and reimbursement from the Board on the ground that the surviving property is of insufficient value to sustain adequate remuneration; but if the Board finds that the surviving property is sufficient in value and that the life salvor can intervene in property salvage proceedings it may dismiss the administrative claim. 
1) The degree of success as measured by the number of persons saved;

2) The personal danger encountered by the salvor, and property risks run;

3) The time expended in the operation;

4) The value of the salvor's property engaged in the operation;

5) Any and all other factors which the Board, in its discretion, deems just and equitable for evaluating the life salvage services rendered.

(b) Any life salvage award made in accordance with the provisions of Section III (a) may have added to it a sum designated by the Board as reimbursement for the necessary expenses and losses incurred by the life salvor on the occasion giving rise to such life salvage award. ${ }^{71}$

\section{Section IV. United States Life Salvage Fund}

(a) Payment of any life salvage award or reimbursement, as ascertained by the United States Life Salvage Administration Board, shall be made from a United States Life Salvage Fund.

(b) The income for the Fund shall be derived in the following manner:

1) Whenever a salvage service shall be rendered in whole or in part by the United States Coast Guard to maritime property, under such circumstances as would entitle a private person to a salvage award, the owner of this property shall pay a sum equal to one percent of its salved value into the Fund.

2) If, in any fiscal year, payments into the Fund shall prove inadequate for life salvage remuneration granted by the Board, Congress may appropriate, in the public interest, such sum as may be required to meet the deficiency. Any sums so appropriated shall be repaid into the Treasury of the United States when, in the opinion of the Board, there exists in the Fund a surplus sufficient to warrant such repayment. ${ }^{72}$

3) The United States shall have a maritime lien of the highest priority on any property salved by the Coast Guard to insure payment into the Fund in accordance with the terms of this Section. This lien may be enforced in the courts of the United States in the same manner as any other salvage lien.

Section V. Nothing contained in any of the foregoing provisions shall be construed as authorizing the Board to award any salvage remuneration to the Coast Guard itself, nor to any of its personnel when acting in performance of their duty to assist and save life and property in peril.

71. The above criteria should assure that the standards used by the Board will not greatly differ from those used by the judiciary in fixing salvage awards. See sources cited note 68 supra.

72. The figure of one percent may prove to be too high, and experience may permit a reduction of this already modest amount. For example, in the fiscal year ending June 30,1949 , the total value of vessels and cargoes assisted by the U.S. Coast Guard was $\$ 199,586, \$ 95$. See Sec'y Treas. Rep. No. 3162 p. 172 (1950). In that year, appruximately $\$ 2,000,000$ would have been available for a Life Salvage Fund. 